\title{
A pseudogene of caffeic acid-o-methyltransferase (COMT) in Acacia mangium: Comparative analysis with other COMT plant promoters
}

\author{
Azmah Abdul Latif ${ }^{1 *}$, Sheh May Tam ${ }^{2}$ and Wickneswari Ratnam ${ }^{1}$ \\ ${ }^{1}$ School of Environmental and Natural Resource Sciences, Faculty of Science and Technology, \\ Universiti Kebangsaan Malaysia, 43650 Bangi Selangor, Malaysia \\ ${ }^{2}$ School of Biosciences, Taylor's University. \\ *Corresponding author: azmahabdlatif@gmail.com
}

\begin{abstract}
Acacia mangium is a prominent tree species in the forest plantation industry of Southeast Asia, grown mainly to produce pulp and paper, and to a lesser extent wood chips and solid wood products. Lignin, a natural complex polymer used by plants for structural support and defence, has to be chemically removed during the production of quality paper. Delignification is very expensive and moreover, is an environmental pollutant. Understanding the complex mechanisms that underlie the regulation of lignin biosynthetic genes requires in-depth knowledge of not only the genes involved but also their regulatory elements. Using Thermal Asymmetric Interlaced PCR, a 770 bp promoter sequence with 93\% identity with COMT1 gene from Acacia auriculiformis $\times$ A. mangium hybrid was isolated from A. mangium. Bioinformatics analysis revealed the presence of cis acting elements commonly found in other lignin biosynthesis genes such as TATA box, CAAT box, W box, AC-I and AC-11 elements. However, a nonsense mutation that created a premature stop codon was found on the first exon. Modelling of MYB transcription factor binding site on this newly isolated pseudogene shows it has binding sites for important transcription factors involved in lignin biosynthesis both in Arabidopsis thaliana and Eucalyptus grandis. Given the remarkable structures of its regulatory region, the possible structure of its transcript was detected using Mfold. Results show the transcript are capable of forming stem loop structures, a characteristic commonly attributed to presence of miRNA. Possible functions of pseudoAmCOMT1 were discussed.
\end{abstract}

KEYWORDS: Pseudogene. Caffeic acid-o-methyltransferase (COMT). Promoter structure. Transcription factors.

\section{INTRODUCTION}

Lignin is a complex aromatic polymer mainly found in plant secondary cell wall (Boerjan et al. 2003) which plays an important role in plant development (Jones et al. 2001) and defence mechanism (Lauvergeat et al. 2001). Presence of lignin on the secondary cell wall of plants gives its rigidity and upright structure (Jones et al. 2001). Lignin polymer consists of three different monomers, which is p-hydroxyphenyl $(\mathrm{H})$, guaiacyl $(\mathrm{G})$ and syringyl (S) units. Angiosperms lignin consists of mainly $G$ and $S$ subunit. Lignification toolbox in many plant species consists of a set of family protein which functions at different level in the production 
of lignin monomer. Genome-wide characterisation of Arabidopsis genome found 10 enzymes which functions in lignin biosynthesis pathway (Raes et al. 2003).

Caffeic acid-o-methyltransferase (COMT) is one of the enzyme specifically involved in $\mathrm{S}$ unit production ( $\mathrm{Li}$ et al. 2000). Similar to other genes involved in lignin biosynthesis pathway, COMT exist as gene family in many plant species. There are high numbers of genes with high sequence similarity with COMT in every plant species. For example, there are 13 COMT-like gene in Arabidopsis thaliana (Raes et al. 2003) and 25 COMT coding sequence in Populus tricchocarpa (Shi et al. 2010). However, only one gene was shown to have high expression in xylem tissues and is predicted to have major function in lignification during development (Raes et al. 2003; Shi et al. 2010). Eucalyptus grandis COMT gene family was shown to have expanded with seven genes and only one was shown to have high expression in xylem tissues (Carocha et al. 2015). The gene family expansion was determined to be results of tandem duplication and segmental duplication event, followed by functional divergence (Carocha et al. 2015). COMT and other genes which function specifically in $S$ lignin production pathway are predicted to have younger evolutionary origins than genes involved in G lignin production (Peter \& Neale 2004).

Acacia mangium, an important forest tree species has an estimated worldwide plantation of 1.4 M ha (Griffin et al. 2011). It is planted widely in South East Asia and used mainly for production of pulp and paper (Griffin et al. 2011). Transcriptome sequencing on Acacia mangium discovered all the ten monolignol biosynthetic genes involved in lignin biosynthetic pathway (Wong et al. 2011). COMT and CCR-like gene were also isolated and characterised from Acacia auriculiformis $\times$ A. mangium hybrid (Sukganah et al. 2013).

Regulatory elements involved in the complex regulatory network of lignin biosynthesis include promoter structures, transcription factors and miRNAs (Shi et al. 2010; Grima-Pettenati et al. 2012; Ong \& Wickneswari 2011). Genes involved in lignin biosynthesis are known to be co-regulated through binding of MYB transcription factors on their promoter region (Zhao \& Dixon 2011). R2R3 MYB transcription factors are also found to be more evolved in woody plants genome (Soler et al. 2015). Through comparative genomic analysis, several sub groups were identified only present in woody plant species and some of its member are later found to also be involved in lignin biosynthesis (Soler et al. 2016).

In this study, a new promoter of a pseudogene with high sequence similarity with COMT is isolated and characterized in silico. The regulatory region of this gene exhibits outstanding characteristics, with presence of ACI and ACII elements, and other cis acting elements commonly found in lignin biosynthetic genes. Comparative analysis with other real COMT promoters shows this promoter has the binding site for some important R2R3 MYB transcription factors involved in regulation of lignin and secondary cell wall biosynthesis. The transcript is capable to form stem loop structure. The possible function of this pseudogene is discussed.

\section{Materials and Method}

Young leave samples of Acacia mangium were obtained from mature trees grown at plot W, Plant Biotechnology Centre, National University of Malaysia, Bangi, Malaysia. Genomic DNA was extracted from 100mg of fresh leaves using QIAGEN DNeasy Plant Mini Kit (Qiagen, Germany) following manufacturer's protocol. Isolation of COMT promoter 
sequence was performed using Thermal Asymmetric Interlaced PCR (TAIL-PCR). Two gene specific primers i.e. GSP1 and GSP2 (Sukganah et al. 2013) were used as reverse primers with an arbitrary degenerate primer AD4 (Thanh et al. 2012) as the forward primer (Table 1). TAIL-PCR was adapted from Liu and Whittier (1995) and briefly described below.

Table 1 Thermal Cycling Conditions

\begin{tabular}{lll}
\hline Reaction & $\begin{array}{l}\text { Number of } \\
\text { Cycles }\end{array}$ & Thermal cycling conditions \\
\hline Primary PCR & 1 & $93^{\circ} \mathrm{C}, 1 \mathrm{~min} ; 95^{\circ} \mathrm{C}, 1 \mathrm{~min}$ \\
& 5 & $94^{\circ} \mathrm{C}, 30 \mathrm{~s} ; 62^{\circ} \mathrm{C}, 1 \mathrm{~min} ; 72^{\circ} \mathrm{C}, 2.5 \mathrm{~min}$ \\
& 1 & $94^{\circ} \mathrm{C}, 30 \mathrm{sec} ; 25^{\circ} \mathrm{C}, 3 \mathrm{~min} ; * 72^{\circ} \mathrm{C}, 2.5 \mathrm{~min}$ \\
& $94^{\circ} \mathrm{C}, 10 \mathrm{~s} ; 68^{\circ} \mathrm{C}, 1 \mathrm{~min} ; 72^{\circ} \mathrm{C}, 2.5 \mathrm{~min}$ \\
& 15 & $94^{\circ} \mathrm{C}, 10 \mathrm{~s} ; 68^{\circ} \mathrm{C}, 1 \mathrm{~min} ; 72^{\circ} \mathrm{C}, 2.5 \mathrm{~min}$ \\
& & $94^{\circ} \mathrm{C}, 10 \mathrm{~s} ; 29^{\circ} \mathrm{C}, 1 \mathrm{~min} ; 72^{\circ} \mathrm{C}, 2.5 \mathrm{~min}$ \\
& 1 & $72^{\circ} \mathrm{C}, 5 \mathrm{~min}$ \\
& $94^{\circ} \mathrm{C}, 10 \mathrm{~s} ; 64^{\circ} \mathrm{C}, 1 \mathrm{~min} ; 72^{\circ} \mathrm{C}, 2.5 \mathrm{~min}$ \\
& $94^{\circ} \mathrm{C}, 10 \mathrm{~s} ; 64^{\circ} \mathrm{C}, 1 \mathrm{~min} ; 72^{\circ} \mathrm{C}, 2.5 \mathrm{~min}$ \\
& $94^{\circ} \mathrm{C}, 10 \mathrm{~s} ; 29^{\circ} \mathrm{C}, 1 \mathrm{~min} ; 72^{\circ} \mathrm{C}, 2.5 \mathrm{~min}$ \\
& & $72^{\circ} \mathrm{C}, 5 \mathrm{~min}$ \\
& 12 & $94^{\circ} \mathrm{C}, 15 \mathrm{~s} ; 29^{\circ} \mathrm{C}, 30 \mathrm{~s} ; 72^{\circ} \mathrm{C}, 2 \mathrm{~min}$ \\
Tertiary PCR & 20 & $72^{\circ} \mathrm{C}, 5 \mathrm{~min}$ \\
\hline
\end{tabular}

* ramping to $72^{\circ} \mathrm{C}$, over $3 \mathrm{~min}$

The primary PCR reaction mixture consisted of $1 \mathrm{U}$ of HS Taq polymerase (Takara Bio Inc., Japan), $1 \times$ Taq polymerase buffer, $200 \mu \mathrm{M}$ dNTPs, $0.2 \mu \mathrm{M}$ GSP 1 primer, $5 \mu \mathrm{M}$ of the AD primer, and $50 \mathrm{ng}$ of genomic DNA. The secondary PCR reaction consisted of $1 \times$ Taq polymerase buffer, $200 \mu \mathrm{M}$ dNTPs, $0.8 \mathrm{U}$ of HS Taq polymerase, $0.2 \mu \mathrm{M}$ GSP2 primer, $4 \mu \mathrm{M}$ of the $\mathrm{AD}$ primer used in the primary reaction, and 50 fold dilution of the primary PCR product. The tertiary PCR mixture consisted of $1 \times$ Taq polymerase buffer supplied with the enzyme, $200 \mu \mathrm{M}$ dNTPs, $0.5 \mathrm{U}$ of HS Taq polymerase, $3 \mu \mathrm{M}$ of the AD primer used in the previous reactions, $0.3 \mu \mathrm{M}$ GSP2 primer, and 10 fold dilution of the secondary PCR product. The thermal cycling conditions are shown in Table 2. PCR products were visualized by electrophoresis on 1.0\% (w/v) agarose gels, purified using NucleoSpin Gel and PCR Cleanup kit and sequenced.

Table 2 Primer utilized for further isolation of 5' and 3' region

\begin{tabular}{ll}
\hline $\begin{array}{l}\text { Primer } \\
\text { Name }\end{array}$ & Primer Sequence (5'to 3') \\
\hline GSP1 & CGAGGGCTGATTTGAGAATCATGGGAAG \\
GSP2 & TGGCTTCCTCGTCGTTGACATGGGTAGG \\
GSP3 & GTTTTTTAATTTACCCCTATGCTACTCCAC \\
M1 & CCACACCCTTTTGCTGGAATCATCACC \\
M2 & GGTTCAGCCGGCGAGACTTAGATAACC \\
AD2 & NGTCGASWGANAWGAA \\
AD4 & AGWGNAGWANCAWAGG \\
\hline
\end{tabular}

After the first round of PCR and sequencing, new primers (GSP3, M1 and M2) were designed based on the sequence of the first fragment obtained to further amplify the 5 ' and 3' regions (Table 2). GSP1, GSP2 and GSP3 were used in combination with AD2 to amplify the 
promoter region. Primers M1 and M2 were used to further amplify the 3' region. All PCR products were visualized by electrophoresis on $1.0 \%$ (w/v) agarose gels. Strong, clear bands were extracted and purified using the NucleoSpin Gel and PCR Clean-up kit (Macherey Nagel) before being sent for sequencing (First Base).

\section{Sequence Analysis}

Sequences were manually cleaned and assembled using BioEdit (Hall 1999) before being subjected to similarity search using BLASTn (Altschul et al., 1990). The promoter sequence was aligned to known COMT1 promoter sequence (HQ317735.1) from Acacia auriculiformis $\times$ A. mangium hybrid (Sukganah et al. 2013) using Clustal Omega (Sievers et al. 2011). Putative cis-acting elements were identified using PlantCARE (Lescot et al. 2002), while the ORF of the gene was detected using ExPASy Translate Tool. The secondary structure of the CDS sequence was predicted using Mfold, a tool for predicting the secondary structure of RNA and DNA (Zuker 2003).

PlantTFDB is a plant transcription factor database which allows the prediction of transcription factor binding on promoter sequence (Jin et al. 2017). Transcription factor binding site on pseudoAmCOMT1, AtCOMT and EgrCOMT1 were predicted using PlantTFDB (Jin et al. 2017). R2R3 MYB transcription factor binding site on pseudoAmCOMT1 and AhgCOMT1 were further modelled with AtCOMT and EgrCOMT1 promoters using Cytoscape (Shannon et al. 2003). All software was used on default parameter.

\section{RESULTS AND DISCUSSIONS}

\section{Isolation and analysis of Promoter}

The initial TAIL-PCR successfully amplified a 400bp fragment of DNA from A. mangium. Analysis of the DNA sequence of this fragment showed part of the promoter, associated 5'UTR and exon 1 of the COMT gene (270bp), with 93\% similarity with AhgCOMT1 from Acacia auriculiformis $\times$ Acacia mangium hybrid. However, a nonsense mutation was detected on exon 1, and in order to confirm this and to increase the length of promoter obtained, new TAIL-PCR primers were successfully used to amplify and extend the 5 ' and 3' regions of this DNA fragment. This resulted in a $800 \mathrm{bp}$ fragment with $92 \%$ similarity to AhgCOMT1. Regions of high sequence similarities are detected within $211 \mathrm{bp}$ of the promoter region to $\sim 110 \mathrm{bp}$ after the start (ATG) codon (Figure 1). Since the presence of the nonsense mutation was confirmed, this sequence was thus named pseudoAmCOMT1 (Genbank accession number: MF488717).

The length of the promoter of pseudoAmCOMT1 is $697 \mathrm{bp}$ and PLANTCARE analysis of the promoter sequence shows presence of multiple cis-acting elements (Figure 1). The core promoter element, TATA box was found at position -22. The 5UTR Py-rich stretch, a cis-acting element which confers high transcription levels was identified at -261 . The elements ACI and ACII which are commonly found in genes involved in lignin and phenylpropanoid pathway, were identified at position -77 and -40 respectively. AC elements are important regulatory elements commonly found in lignin biosynthetic genes and known to be the target for binding of both activator and repressor protein. Presence of AC elements in almost all promoters of lignin biosynthetic genes enables coordinated gene expression towards xylem tissues (Zhou et al. 2009). AC elements were previously reported to be absent 
in most COMT genes (Raes et al. 2003), but expected to be more degenerative and could not be picked up by bioinformatics analysis (Zhou et al. 2009).

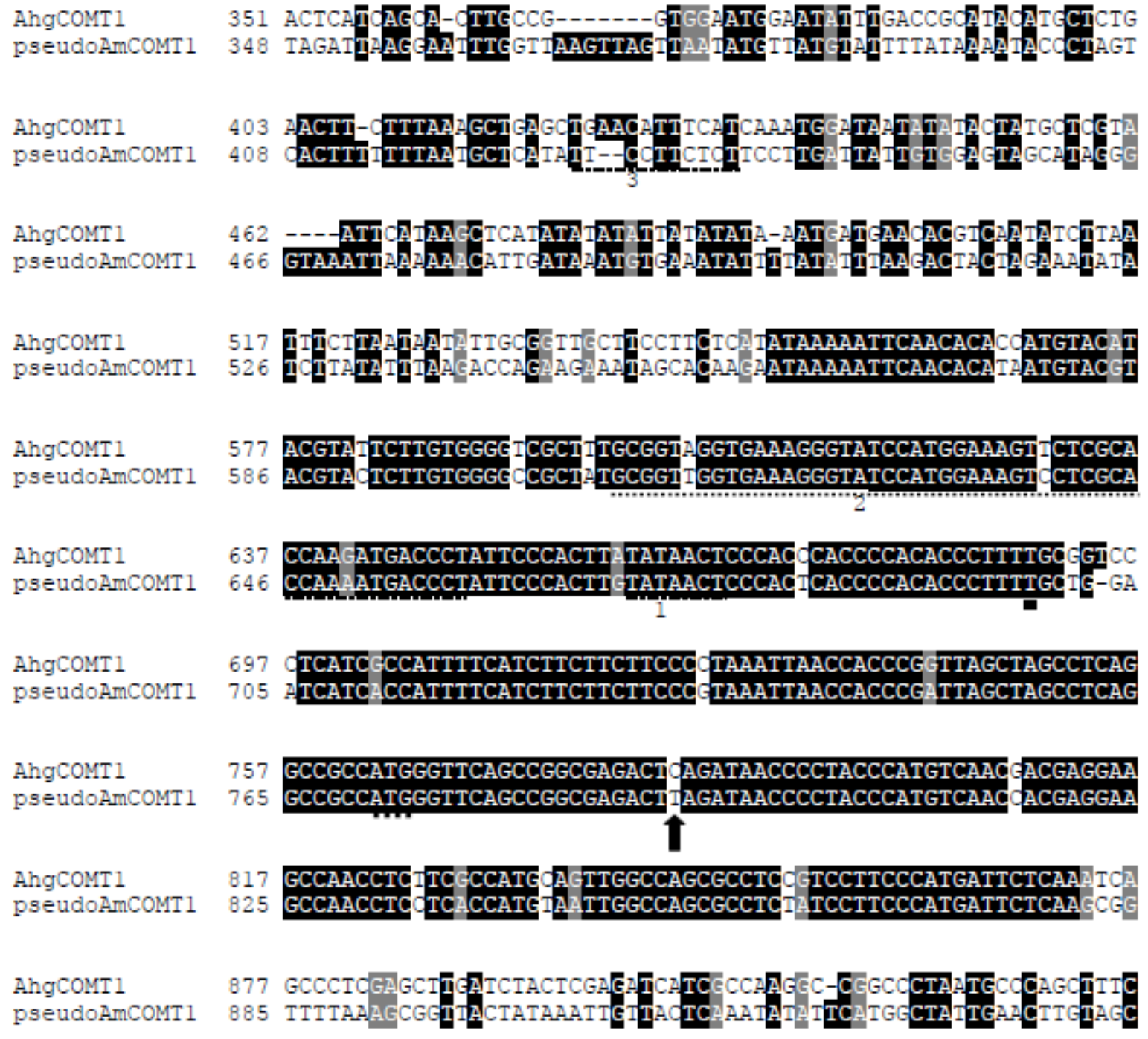

Fig. 1 Alignment of pseudoAmCOMT1 and AhgCOMT1. Transcription start site is marked with thick underline. Translation start site (ATG) is marked with dashes. Important cis acting elements are underlined with dashes and numbered. 1: TATA box, 2: ACI and ACII elements, 3: 5UTR Py-rich stretch. Nonsense mutation that created premature stop codon marked with an arrow.

Multiple cis elements that function in light responsiveness such as the ATCT-motif, Box I, GA-motif and GT1-motif were also identified in this promoter at positions -345, -256 and -330 respectively. This is not surprising as expressions of lignin genes are also known to be affected by light, the circadian clock and sugar levels (Rogers et al. 2005). Other elements identified include $\mathrm{W}$ box which functions in plant defence against pathogens and two motifs GCN4 and Skn-1 which regulate endospermic gene expression, at -619 and -43 . Abscisic acid responsiveness motif, ABRE was found at -110 whilst an ARE motif that functions in anaerobic induction was shown at -496 . P-box, a motif implicated in gibberellin response was found at +2 . Overall, it is noted that similar sets of cis-acting elements were also reported from promoters of other lignin genes such as cinnamoyl-CoA reductase (CCR) and cinnamyl alcohol dehydrogenase (CAD) (Prashant et al. 2012; Lacombe et al. 2000). 
bioRxiv preprint doi: https://doi org/10.1101/269654 this version posted February 22. 2018. The copyriaht holder for this preprint (which was not certified by peer review) is the author/funder, who has granted bioRxiv a license to display the preprint in perpetuity. It is made available under aCC-BY-NC-ND 4.0 International license.

\section{Transcription Factor Binding Site Comparative Analysis}

In silico analysis of pseudoAmCOMT1 revealed the presence of multiple cis-elements that may serve as binding sites for transcription factors with important functions in lignin biosynthesis. To further explore this, PlantTFDB (Jin et al. 2017) was used to obtain comparative models of transcription factors binding on regulatory regions of pseudoAmCOMT1, AhgCOMT1 and AtCOMT (Figure 2) as well as pseudoAmCOMT1, AhgCOMT1 and EgrCOMT1 (Figure 3). The model shows interactions with MYB gene family members, such as AtMYB46 and AtMYB83 which play the role of master regulatory switch in secondary cell wall biosynthesis (Zhong and Ye 2012; McCarthy et al. 2009; Ko et al. 2009). Both AtMYB46 and AtMYB83 function to activate AtMYB58, AtMYB63 and AtMYB85 which are on the next level of the regulation cascade (Zhong et al. 2007, McCarthy et al. 2009). However, it was recently shown that their mode of action was not restricted to just downstream activation of another set of transcription factors, but instead they could also directly activate some lignin genes through secondary wall MYB-responsive element (SMRE) binding site (consensus motif $\mathrm{ACC}(\mathrm{A} / \mathrm{T}) \mathrm{A}(\mathrm{A} / \mathrm{C})(\mathrm{T} / \mathrm{C})$ ) in the promoter region (Zhong \& Ye 2012).

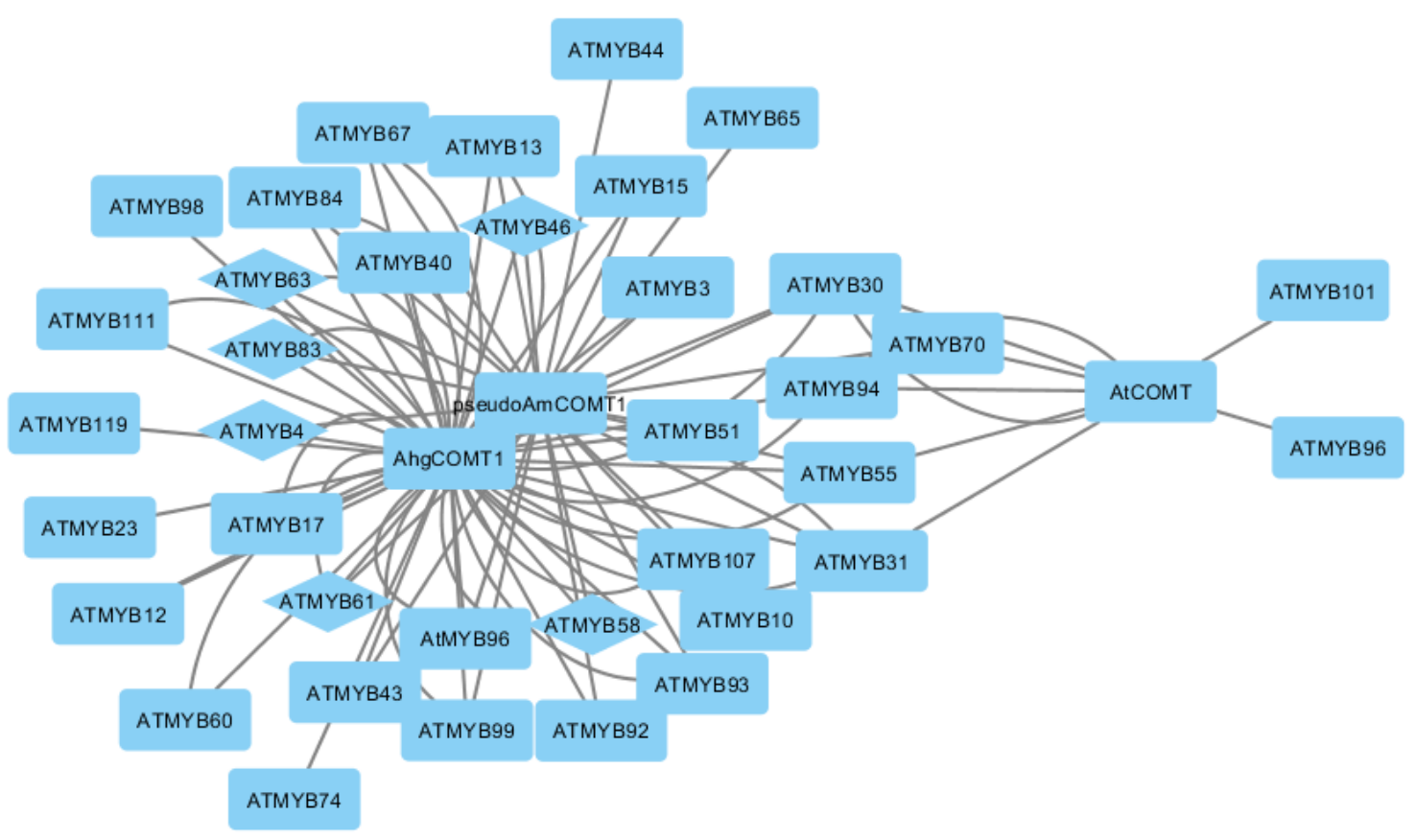

Fig. 2 Transcription factor binding site model of pseudoAmCOMT1, AhgCOMT1 and AtCOMT. Important transcription factors involved in lignin and secondary cell wall biosynthesis are shown in diamond shape. 
AtMYB58, AtMYB63 and AtMYB85 are three transcription factors which function specifically in lignin biosynthesis regulation. PseudoAmCOMT1 and AhgCOMT1 are shown to have binding sites for both AtMYB58 and AtMYB63. These three transcription factors were found to coordinately activate the whole lignin biosynthetic genes by binding to the AC elements in their promoter region, except for $F 5 H$ (Zhou et al. 2009). Although the binding sites for MYB58 and MYB63 on AtCOMT were not detected using bioinformatics analysis, these two transcription factors were shown to regulate the expression of AtCOMT gene (Zhao \& Dixon 2009).

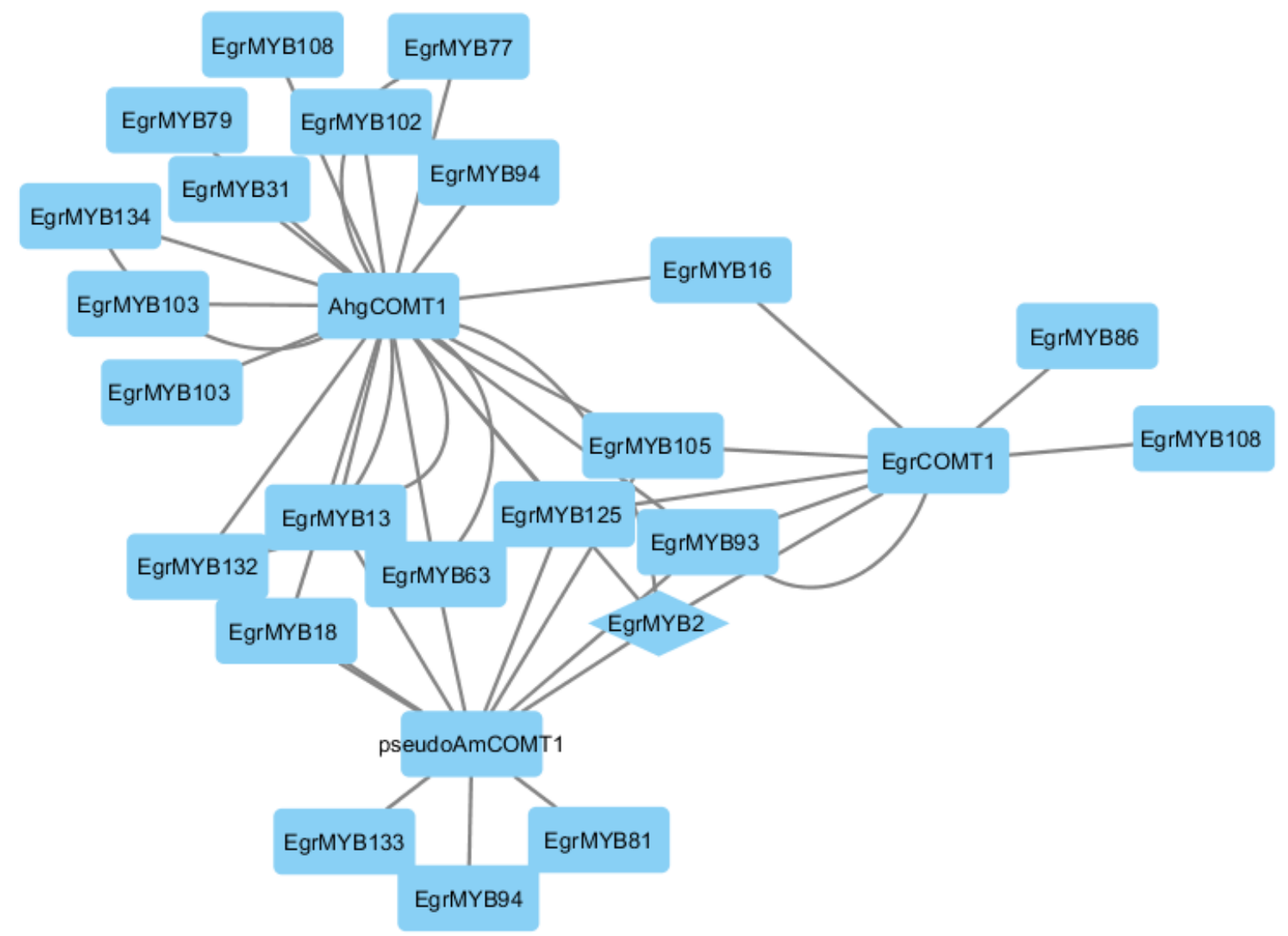

Fig. 3 Transcription factor binding site model of pseudoAmCOMT1, AhgCOMT1 and EgrCOMT1. Important transcription factors involved in lignin and secondary cell wall biosynthesis are shown in diamond shape.

PseudoAmCOMTl and AhgCOMTl are also identified to have binding site for AtMYB61, which was responsible for causing ectopic lignification in Arabidopsis when overexpressed (Newman et al. 2004). AtMYB13, AtMYB15 and AtMYB10 which are part of subgroup $\mathrm{S} 2 \& 3$ are also predicted to have binding sites on pseudoAmCOMT1 and AhgCOMT1 (Soler et al. 2015). Both pseudoAmCOMT1 and AtCOMT promoters are shown to have binding site for AtMYB55 which is a member of subgroup S13 (Soler et al. 2015). Members of both subgroups (S2\&3 and S13) are predicted to be involved in secondary cell wall formation in Arabidopsis. In addition, AtCOMT is also shown to have binding sites for AtMYB70, AtMYB31, AtMYB96, AtMYB30, AtMYB101 and AtMYB94. AtMYB96 and AtMYB94 are members of Subgroup 1 which is predicted to be involved in plant defence 
mechanism (Soler et al. 2015). PseudoAmCOMT1 and AhgCOMT1 are also shown to have binding site for AtMYB4, an important repressor in lignin biosynthesis pathway (Jin et al. 2000).

Results of the transcription factor binding site model for pseudoAmCOMT1, AhgCOMTl and EgrCOMT1 predicted all three promoters to have a binding site for EgrMYB2, an important transcription factor known to be a master regulator of secondary cell wall biosynthesis in Eucalyptus (Goicoechea et al. 2005). Overexpression of EgMYB2 in tobacco caused dramatic increase in secondary wall thickness, as well as alteration in lignin profiles, where the S:G ratio was increased. Transcript analysis showed upregulation of EgMYB2 caused an increase of 40 folds of COMT, CCoAOMT, F5H and C3H genes expression while $C C R$ and $C A D$ were upregulated five fold (Goicoechea et al. 2005). This model indicates the difference might be partly because of the genes' promoter structure. Both pseudoAmCOMT1 and EgrCOMT1 promoters also have binding site for EgrMYB93 with the former with the former having additional binding sites for EgrMYB132 and EgrMYB133. All these three transcription factors belong to groups which are expected to have important functions in the regulation of secondary cell wall biosynthesis (Soler et al. 2015). Interestingly, the binding site for EgrMYB81, a member of the 'woody-expanded subgroup', S6 (Soler et al. 2015) was detected from pseudoAmCOMT1. Members of this subgroup were identified to be present significantly more in woody plant species (Soler et al. 2015).

Given the strong regulatory elements present in the promoter region, the transcript sequence of pseudoAmCOMT1 was subjected to secondary structure prediction. Results show that the transcript is able to form hairpin structures with $\Delta \mathrm{G}=-1.6$ (a) and -1.3 (b \& c) (Figure 5). Generally, the ability to form hairpin precursor indicates the formation of miRNA (Ambros et al. 2003) and suggests the possibility of pseudoAmCOMT1 in regulating its paralogous genes.

a

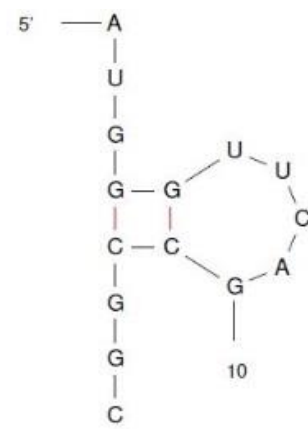

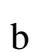
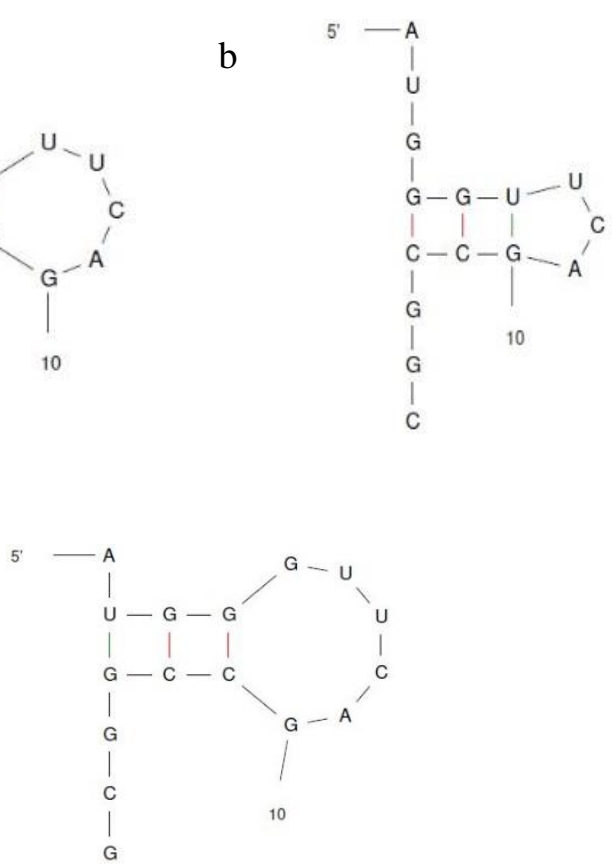

Fig. 4 Hairpin structures of pseudoAmCOMT1 transcript. 
COMT gene family were identified to be among the most expanded gene family among genes involved in lignin biosynthesis, and biotic defence were predicted to be the driving force for the rapid expansion (Xu et al. 2009). Rate of tandem duplication of COMT genes in Eucalyptus grandis exceeds overall frequency of tandem duplication within the genome (Carocha et al. 2014; Myburg et al. 2014). Expressions of most of these tandem duplicated genes was found to be strongly responsive towards environmental stimuli (Carocha et al. 2014).

Recent findings shows a group of small interfering RNAs with young evolutionary origins, phasiRNAs targets genes in the same family from where they are derived (Zheng et al. 2015). This group of small interfering RNAs were found to have nearly perfect match to the genes in the same family as their originating loci and play important role in disease resistant within dicot species (Zheng et al. 2015). Some phasiRNAs were found to negatively regulate disease resistance genes in A. thaliana (Boccara et al. 2014). Members of COMT gene family, along with other genes involved in lignification, are known to also take part in plant resistance against pathogen (Toquin et al. 2003; Lauvergeat et al. 2001). In fact, resistance against pathogen are expected to be the major driving force of COMT gene family expansion (Xu et al. 2009).

Interestingly, downregulation of COMT in Poplar and tobacco causes only minor effect on plant morphology. While downregulation of most of the lignin biosynthetic genes causes reduction in lignin content and an abnormal phenotype, downregulation of COMT in both cases caused reduction in S lignin unit, but the overall lignin remain unchanged as 5hydroxyconiferyl alcohol was incorporated (Atanassova et al. 1995; Doorsselaere et al. 1995). This new type of lignin composition was also found to have more cross link and thus, more resistant to degradation (Jouanin et al. 2000). Possible role of pseudoAmCOMT1 in regulating its orthologous genes however, could only be confirmed through future functional studies.

\section{ACKNOWLEDGEMENTS}

We would like to thank Ministry of Science and Technology and Innovation (MOSTI), Malaysia (02-02-18-SF-1117/ST-2013-012) for funding.

\section{COMPLIANCE WITH ETHICAL STANDARDS:}

Conflict of Interest: All authors declare that they have no conflict of interest.

\section{REFERENCES}

Altschul, S., F., Gish, W., Miller, W., Myers, E., W. \& Lipman, D., J. 1990. Basic local alignment search tool. Journal of Molecular Biology 215(3):403-410.

Barakat, A., Choi, A., Yassin, N., B., Park, J., S., Sun, Z. \& Carlson, J., E. 2011b. Comparative genomics and evolutionary analyses of the $O$-methyltransferase gene family in Populus. Gene 479(1-2):37-46. 
Boerjan, W., Ralph, J. \& Baucher, M. 2003. Lignin biosynthesis. Annual Review of Plant Biology 54: 519-546.

Boudet, A., M., Kajita, S., Grima-Pettenati, J., Goffner, D. 2003. Lignins and lignocellulosics: a better control of synthesis for new and improved uses. Trends in Plant Science 8(12):576-81.

Carocha, V., Hefer, C., Cassan-wang H., Fevereiro, P., Alexander, A., Paiva, J., A., P., \& Grima-Pettenati, J. 2015. Genome-wide analysis of the lignin toolbox of Eucalyptus grandis. New Phytology. 206(4): 1297-1313.

Goicoechea, M., Lacombe, E., Legay, S., Mihaljevic, S., Rech, P., Jauneau, A., Lapierre, C., Pollet, B., Verhaegen, D., Chaubet-Gigot, N. \& Grima-Pettenati, J. 2005. EgMYB2, a new transcriptional activator from Eucalyptus xylem, regulates secondary cell wall formation and lignin biosynthesis. The Plant Journal 43(4): 553-567.

Griffin, A., R., Midgley, S., J., Bush, D., Cunningham, P., J. \& Rinaudo, A. T. 2011. Global uses of Australian acacias - recent trends and future prospects. Diversity and Distributions 17(5): 837-847.

Grima-Pettenati, J. \& Goffner, D. 1999. Lignin genetic engineering revisited. Plant Science 145(2):51-65

Grima-Pettenati, J., Soler, M.; Camargo, E., L., O. \& Hua, W. 2012. Transcriptional regulation of the lignin biosynthetic pathway revisited: new players and insights. Advances in Botanical Research. Burlington: Academic Press

Hall, T.A. 1999. BioEdit: a user-friendly biological sequence alignment editor and analysis program for Windows 95/98/NT. Nucl. Acids. Symp. Ser. 41:95-98.

Jin, H., Cominelli, E., Bailey, P., Parr, A., Mehrtens, F., Jones, J., Tonelli, C., Weisshaar, B. \& Martin, C. 2000. Transcriptional repression by AtMYB4 controls production of UV-protecting sunscreens in Arabidopsis. The EMBO Journal 19(22): 6150-6161.

Jin, J., Tian, F., Yang, D-C, Meng, Y-Q, Kong, L., Luo, J. \& Gao, G. 2017. PlantTFDB 4.0: toward a central hub for transcription factors and regulatory interactions in plants. Nucleic Acids Research 45(D1): D1040-D1045.

Ko, J., H., Kim, W., C. \& Han, K. H. 2009. Ectopic expression of MYB46 identifies transcriptional regulatory genes involved in secondary wall biosynthesis in Arabidopsis. The Plant Journal 60(4): 649-665.

Lacombe, E., Van Doorsselaere, J., Boerjan, W., Boudet, A., M. \& Grima-Pettenati, J. 2000. Characterization of cis-elements required for vascular expression of the cinnamoyl CoA reductase gene and for protein-DNA complex formation. The Plant Journal 23(5): 663-676.

Lauvergeat, V., Lacomme, C., Lacombe, E., Lasserre, E., Roby, D. \& Grima-Pettenati, J. 2001. Two cinnamoyl-CoA reductase (CCR) genes from Arabidopsis thaliana are 
differentially expressed during development and in response to infection with pathogenic bacteria. Phytochemistry 57(7):1187-1195.

Lescot, M., Déhais, P., Thijs, G., Marchal, K., Moreau, Y., Van de Peer, Y., Rouzé, P. \& Rombauts, S. 2002. PlantCARE, a database of plant cis-acting regulatory elements and a portal to tools for in silico analysis of promoter sequences. Nucleic Acids Research 30(1):325-327.

Liu, Y-G. \& Whittier, R. F. 1995. Thermal asymmetric interlaced PCR: automatable amplification and sequencing of insert end fragments from P1 and YAC clones for chromosome walking. Genomics 25(3): 674-681

Mazars, G., R., Moyret, C., Jeanteur, P. \& Theillet, C., G. 1991. Direct sequencing by thermal asymmetric PCR. Nucleic Acids Research. 19(17): 4783.

McCarthy, R., L., Zhong, R. \& Ye, Z. H. 2009. MYB83 is a direct target of SND1 and acts redundantly with MYB46 in the regulation of secondary cell wall biosynthesis in Arabidopsis. Plant \& Cell Physiology 50(11): 1950-1964.

Myburg, A., A., Grattapaglia, D., Tuskan, G., A., Hellsten, U., Hayes, R., D., Grimwood, J., Jenkins, J., Lindquist, E., Tice, H., Bauer, D., Goodstein, D., M., Dubchak, I., Poliakov, A., Mizrachi, E., Kullan, A., R., Hussey, S., G., Pinard, D., van der Merwe, K., Singh, P., van Jaarsveld, I., Silva-Junior, O., B., Togawa, R., C., Pappas, M., R., Faria, D., A., Sansaloni, C., P., Petroli, C., D., Yang, X., Ranjan, P., Tschaplinski, T., J., Ye, C., Y., Li, T., Sterck, L., Vanneste, K., Murat, F., Soler, M., Clemente, H., S., Saidi, N., Cassan-Wang, H., Dunand, C., Hefer, C., A., Bornberg-Bauer, E., Kersting, A., R., Vining, K., Amarasinghe, V., Ranik, M., Naithani, S., Elser, J., Boyd, A., E., Liston, A., Spatafora, J., W., Dharmwardhana, P., Raja, R., Sullivan, C., Romanel, E., Alves-Ferreira, M., Külheim, C., Foley, W., Carocha, V., Paiva, J., Kudrna, D., Brommonschenkel, S., H., Pasquali, G., Byrne, M., Rigault, P., Tibbits, J., Spokevicius, A., Jones, R., C., Steane, D., A., Vaillancourt, R., E., Potts, B., M., Joubert, F., Barry, K., Pappas, G., J., Strauss, S., H., Jaiswal, P., Grima-Pettenati, J., Salse, J., Van de Peer, Y., Rokhsar, D., S. \& Schmutz, J. 2014. The genome of Eucalyptus grandis. Nature 510(7505): 356-362.

Newman, L., J., Perazza, D., E., Juda, L. \& Campbell, M. M. 2004. Involvement of the R2R3-MYB, AtMYB61, in the ectopic lignification and dark-photomorphogenic components of the det3 mutant phenotype. The Plant Journal 37(2): 239-50.

Pink, R., C., Wicks, K., Caley, D., P., Punch, E., K., Jacobs, L. \& Carter D., R., F. 2011. Pseudogenes: Pseudo-functional or key regulators in health and disease? RNA 17(5): 792-798.

Podlaha, O. \& Zhang, J. 2010. Pseudogenes and Their Evolution. Encyclopedia of Life Sciences (ELS). Chichester: John Wiley \& Sons, Ltd.

Prashant, S., Sunita, M., S., L., Sirisha, V., L., Bhaskar, V., V., Rao, A., M., Narasu, M., L., \& Kavi Kishor P., B. 2012. Isolation of cinnamoyl CoA reductase and cinnamyl alcohol dehydrogenase gene promoters from Leucaena leucocephala, a leguminous 
tree species, and characterization of tissue-specific activity in transgenic tobacco. Plant Cell, Tissue and Organ Culture. 108(3): 421-436.

Raes, J., Rohde , A., Christensen, J., Van de Peer, Y. \& Boerjan, W. 2003. Genome wide characterization of the lignification toolbox in Arabidopsis. Plant Physiology 133(3): $1051-1071$.

Rogers, L., A., Dubos, C., Cullis, I., F., Surman, C., Poole, M., Willment, J., Mansfield, S., D. \& Campbell, M., M. 2005. Light, the circadian clock, and sugar perception in the control of lignin biosynthesis. Journal of Experimental Botany 56(416): 1651-1663

Shannon, P., Markiel, A., Ozier, O., Baliga, N. S., Wang, J. T., Ramage, D., Amin, N., Schwikowski, B. \& Ideker, T. 2003. Cytoscape: A Software Environment for Integrated Models of Biomolecular Interaction Networks. Genome Research 13(11): 2498-2504.

Shi, R., Sun, Y., H., Li, Q., Heber, S., Sederoff, R. \& Chiang, V., L. 2010. Towards a Systems Approach for lignin biosynthesis in Populus trichocarpa: Transcript Abundance and Specificity of the Monolignol Biosynthetic Genes. Plant and Cell Physiology. 51(1):144-63.

Sievers, F., Wilm, A., Dineen, D., Gibson, T., J., Karplus, K., Li, W., Lopez, R., McWilliam, H., Remmert, M., Söding, J., Thompson, J., D. \& Higginsa, D., G. 2011. Fast, scalable generation of high-quality protein multiple sequence alignments using Clustal Omega. Molecular Systems Biology 7: 539.

Soler, M., Camargo, E., L., Carocha, V., Cassan-Wang, H., San Clemente, H., Savelli, B., Hefer, C., A., Paiva, J., A., Myburg, A., A. \& Grima-Pettenati, J. 2015. The Eucalyptus grandis R2R3-MYB transcription factor family: evidence for woody growth-related evolution and function. New Phytologist. 206(4):1364-1377.

Sukganah, A., Choong, C., Y., Russell, J. Neale, D. \& Wickneswari, R. 2013. Nucleotide sequence analysis of two lignin genes in Acacia auriculiformis $\times$ Acacia mangium hybrid for enhancement of wood pulp quality. Tree Genetics \& Genomes 9(5): 13691381.

Thanh, T., Chi, V., T., Abdullah, M., P., Omar, H. \& Napis, S. 2012. Efficiency of ligationmediated PCR and TAIL-PCR methods for isolation of RbcS promoter sequences from green microalgae Ankistrodesmus convolutus. Molecular Biology 46(1):64-70.

Toquin, V., Grausem, B., Geoffroy, P. \& Legrand, M. 2003. Structure of the tobacco caffeic acid $O$-methyltransferase (COMT) II gene: identification of promoter sequences involved in gene inducibility by various stimuli. Plant Molecular Biology 52(3): 495509

Whetten, R., W., MacKay, J., J. \& Sederoff, R., R. 1998. Recent advances in understanding lignin biosynthesis. Annual Review of Plant Physiology and Plant Molecular Biology 49: 585-609. 
Wong, M., M., Cannon, C., H. \& Wickneswari, R. 2011. Identification of lignin genes and regulatory sequences involved in secondary cell wall formation in Acacia auriculiformis and Acacia mangium via de novo transcriptome sequencing. BMC Genomics 12:342

Xu, Z., Zhang, D., Hu, J., Zhou, X., Ye, X., Reichel, K., L., Stewart, N., R., Syrenne, R., D., Yang, X., Gao, P., Shi, W., Doeppke, C., Sykes, R., W., Burris, J., N., Bozell, J., J., Cheng, M., Z., Hayes, D., G., Labbe, N., Davis, M., Stewart, C., N., Jr. \& Yuan, J., S. 2009. Comparative genome analysis of lignin biosynthesis gene families across the plant kingdom. BMC Bioinformatics 10(Suppl 11):S3

Zhao, Q. \& Dixon, R., A. 2011. Transcriptional networks for lignin biosynthesis: more complex than we thought? Trends in Plant Science 16(4):227-233

Zhong, R., Richardson, E., A. \& Ye, Z. H. 2007. The MYB46 transcription factor is a direct target of SND1 and regulates secondary wall biosynthesis in Arabidopsis. The Plant Cell 19(9): 2776-2792.

Zhong, R. \& Ye, Z. H. 2012. MYB46 and MYB83 bind to the SMRE sites and directly activate a suite of transcription factors and secondary wall biosynthetic genes. Plant and Cell Physiology 53(2): 368-380.

Zhou, J., Lee, C., Zhong, R. \& Ye, Z., H. 2009. MYB58 and MYB63 are transcriptional activators of the lignin biosynthetic pathway during secondary cell wall formation in Arabidopsis. Plant Cell 21(1): 248-266

Zou, C., Lehti-Shiu, M., D., Thibaud-Nissen, F., Prakash, T., Buell, C., R. \& Shiu, S, H. 2009. Evolutionary and expression signatures of pseudogenes in Arabidopsis and rice. Plant Physiology 151(1): 3-15.

Zuker, M. 2003. Mfold web server for nucleic acid folding and hybridization prediction. Nucleic Acids Research 31(13):3406-3415. 